\title{
READERS
Insight
}

Journal of Management Info (JMI)

ISSN:2313-3376

www.readersinsight.net/jmi

Mh

\section{Relationship between inflation and other macro economic variables in Pakistan}

\author{
Adnan Ali $^{1^{*}}$, Dr. Farzand Ali Jan², Sami Ullah Khan ${ }^{3}$ \\ ${ }^{1}$ Department of Management Sciences (SBBUS) \\ ${ }^{2}$ Comsats University of Technology \\ ${ }^{3}$ Institute of Business and Management Sciences \\ *Corresponding author: adnanmsd1458@gmail.com
}

\begin{abstract}
Conventionally, it is claimed that persistently higher deficit in government budget may cause the inflation to rise in the long run but this relationship is not conclusive empirically. Therefore, the present study is aimed to determine the relationship between inflation and other studied variables of macroeconomics i.e. fiscal deficit and supply of money in the short run as well as in the long run in Pakistan. The bound testing approach to co-integration and VAR model, established within an autoregressive distributed lag (ARDL) is used to analyze data of time series covering the period of time from 1960 to 2010 for examining the studied variables both in short run as well as in long run. The conclusion of the study shows that the relationship between the studied variables is insignificant in the long run but the outcomes of VAR model illustrate that a short run positive relationship between the studied variables cannot be ignored. The study further indicates that $1 \%$ change in budget deficit and money supply caused a change in inflation by 0.29 and 0.31 times respectively in the short run. The results provide strong evidence that the government may target reducing the inflation by generating domestic economic resources to boost the economic growth instead of reducing budget deficit.
\end{abstract}

Keywords: Budget Deficit, Inflation, Money Supply, Autoregressive Distributed Lag.

(C) Readers Insight Publication

\section{Introduction}

The relationship between inflation and other macroeconomic variables i.e. fiscal deficit and supply of money is examined universally by different economists, in which most of the studies concluded that inflation is the result of budget deficit, because when monetization occurs to finance the budget deficit, it will lead to rise the supply of money which directly affects the inflation to rise in the long run. This is the result of quantity theory of money which shows that when the money supply increases, the inflation level also increases. The relationship between inflation and other macroeconomic variables is a serious issue in an economic literature which is of great importance to every government of the world. Studies provided that higher deficit in budget affects to grow the monetary base, which brings the supply of money to increase and thus finally leads to increase the inflation rate. The types and modes of financing have different effects of fiscal deficit on the rate inflation. The key results of the empirical studies evaluating the relationship between inflation and fiscal deficit shows robust evidence that fiscal deficit financed by money creation, cause the inflation to increase (Agha and Khan, 2006).

In macroeconomics, a deep rooted theory is that the governments with persistent high budget deficit, adopts the policy of money creation to finance their fiscal deficits, which leads to increase the inflation finally (Sargent and Wallace, 1981). But the present theory does not indicate the significance of other tools through which inflation can be increase consistently.
Budget deficit-inflation nexus is an important issue in the economies of developing as well as the world's developed countries. A large number of studies have been conducted on the issue and resulted empirically the association between inflation and fiscal deficit in developed countries (Dogas, 1992; Hamburger and Zwick, 1981; Sowa, 1994, Ali, 2003 and Hondroyiannis and Papatrou, (1994, 1997); Ahking and Miller, 1985; Dawyer, 1982; Metin, 1995). The findings of these studies revealed that, the inflation and budget deficit do not correlate each other neither in the short run and nor in the long run.

The evidence for existence of a positive and considerable association between inflation and fiscal deficit has been presented too (Sowa, 1994; Choudhary and Parai, 1991; Dogas, 1992; Buiter and Patel, 1992; Metin, (1995, 1998); Abiola, 1995; Oyejide, 1972; Darrat, 2000; Siddiqui, 1989; Egwaikhide et al., 1996; Abiodum and James, 2000).

The evidence that there is present a positive long run association between budget deficit and inflation in Pakistan has also been presented (Chaudhary \& Ahmad, 1995; Agha and Khan, 2006; Sarfaraz and Anwar, 2009).

The studies that have concluded no relationship in long run between inflation and budget deficit in Pakistan have also been presented (Bilquees, 1988; Mukhtar and Zakaria, 2010; Saleem et al., 2013 and Khan and Gill, 2010).

\section{Inflation, budget deficit and pakistan economy}

In the literature of developing countries, the "Fiscal View" of inflation has been specially well recognized, which has accepted for a long time that inefficient collection of tax, unstable political situations 
and restricted access to foreign debts causes to decrease the comparative cost of printing the money and increase reliance on inflation tax (Cukierman et al., 1992; Alesina and Drazen, 1991; Calvo and Vegh, 1999).

According to historical literature, inflation is a fiscal as well as monetary phenomenon. Generally inflation can be defined as "the gradual and persistent rise in general price level in a given time period as measured by indices such as WPI (whole sale price index), GDP deflator, CPI (consumer price index) and SPI (sensitive price index) etc. Inflation is grouped into the following categories as, when there is an increase of $5 \%$ or less than $5 \%$ then it will be called as creeping inflation and this is favorable for the economy. When it is rising by $5-$ $10 \%$, then the inflation is referred as walking inflation. If it is rising by above $10 \%$, then it is called running inflation, and when it crosses the $50 \%$, so it is called hyperinflation (Haider and Khan, 2007). As commonly found that since last many years, there is double digit inflation in Pakistan. The sensitive price index (SPI) rose by more than $15 \%$ in the year 1981 and 1982 , and more than $12.5 \%$ in the year 1990 and 1991. Likewise, the CPI rose by $11.5 \%$ in the year 1981 and 1982, and more than $12.5 \%$ in financial year 1990 and 1991. For several years the GDP deflator showed more than $10 \%$ increase (Choudhary and Ahmed, 1995).

On the other hand, government budget deficit is a situation when government's total expenditures exceed government's total revenues for a given period of time. Economics experts claimed that inflation is totally a monetary issue and it is often believed that financing of budget deficit through money creation is the main cause of inflation in developing countries. When the rate of money supply growth exceeds the rate of growth of the economy then inflation occur. During 197080 , the budget deficit was about $7.6 \%$ of Gross domestic product (GDP) and it was about $7.8 \%$ in 1980 . The inflation rate was about $8.6 \%$ during $1987-88$ and was about $7.9 \%$ during 1992-93 in Pakistan (Choudhary and Ahmed, 1995).

The factors that have left behind Pakistan from achieving the favorable economic conditions, fiscal deficit and inflation are the main factors. Pakistan is facing the problem of persistent in fiscal deficit; therefore it is believed that budget deficit is the main cause of inflation in Pakistan. The impact of fiscal deficit in budget over inflation depends on how it is financed. Budget deficit financing can be done through the following ways. (1). Domestic borrowing i.e. bond release or borrowing from banking system which raises the interest rate, causes fall in private investment and increases domestic debt as well. (2). External borrowings which means borrowing from abroad which leads to a current deficit and sometimes to an external debt crises. (3). Monetary base which means printing of new notes that directly affect the inflation to rise (Choudhary and Ahmed, 1995).

\section{Money supply, inflation and pakistan economy}

Money supply and inflation are interrelated in the economy of every country. The money supply may be defined as the quantity of money circulating in a country during a specific time period. Inflation is a persistent increase in general price level over a given time period which is usually measured through the Price Indexes such as CPI (Consumer price index), WPI (Wholesale price index), SPI (Sensitive price index) and GDP Deflator etc. The inflation increases because of the circulation of money in the economy. The increasing trend in supply of money may be defined as the direct transmission of monetary mechanism, which explains that the increased supply of money compel the people to spend their surplus money over demand of money (Sarfaraz and Anwar, 2009).

To set the target level of inflation for some future period of time may be treated as important guidelines for both the private and public sector of a country. If economic experts can predict the future fluctuations in inflation, then they can use their resources more effectively and efficiently. For this purpose the central bank of a country adopt the policy of targeting reasonable accurate forecasts of future inflation. In order to get success in this field, understanding and measuring the significance of the determinants of inflation are important. Among the determinants of future inflation, money supply is at the top. Money supply can be focused as an indicator of future inflation, if a stable and equilibrium association between inflation and supply of money exists. Although the empirical results of the relationships between supply of money and inflation in different countries vary from one study to another (Abdul Qayyum, 2006).

When the government of a country aims to control and decrease the rate of inflation, then they should measure and examine the supply of money and should apply the fiscal policy for reduction in money supply circulated in the economy. In Pakistan, the state bank (SBP) is responsible for maintaining stable price level and promotion of growth in the country. For controlling inflation with in the level specified by the government the money supply is used as a tool by state bank of Pakistan. The data shows that money supply has exceeded the targeted level for last four years continuously (20022005), because of loose monetary policy which was adopted for supporting the growth of the country. However the loose monetary policy caused the inflation to reach double digit in 2005. Therefore inflation may be regarded as tax on holding of money. For the year 2005 the inflation tax was calculated at Rs. 61929 million or 0.97 .90 $\%$ of GDP. In 2003-2004 the monetary policy was framed wrongly, as the inflation was maintained at a very low level. After 2005, the monetary policy was framed for increase in the rate of inflation (Abdul-Qayyum, 2006).

Abd-ul-Qayyum (2006) conducted a study in Pakistan on "Inflation, growth and money in Pakistan" to examine the correlation between inflation and excess supply of money in Pakistan to investigate the monetaristic view that inflation is due to money growth. To find the relationship the study used Quantity theory of money as model of the study and money supply growth, inflation rate and real growth of GDP as parameters of the study for the period from 1960 to 2005. The study revealed that inflation and growth of money have a robust and positive relationship among themselves. The result further confirmed that growth in money affect GDP growth in first step and then affects inflation in the second step in Pakistan.

\section{Theoretical aspect of inflation, money supply \& budget deficit}

Some of the theories regarding the study are discussed below;

Classical Theory of Inflation

According to this theory, "inflation is directly proportional to the increase in supply of money; given the output growth level remains the same". This theory is based on quantity theory of money, postulated by Adam Smith. This theory does not explain the mechanism through which inflation is caused by increase in money supply. Another version of this theory is the neo-classical theory of inflation which states that "increase in demand for money causes the inflation at proportionate level".

\section{Keynesian Theory of Inflation}

Keynes put forwarded this theory which states that "aggregate demand can be increased also due to real factors", which means that budget deficit (govt. expenditures) may stimulate the level of output growth. Keynes introduces the concept of "inflationary gap" (the planned government expenditures over the available output at full employment). Keynes stated that at full employment output level, budget deficit (inflationary gap) is inflationary but at less than full employment output level, the budget deficit is not inflationary.

\section{The new Classical Theory of Inflation}

This is the modified version of the classical theory of money which states that "money supply causes the inflation solely". But this theory deviates from the classical theory in the following respects. (a). There is no proportionality, (b). Modern monetarists distinguish between short run and long run, they argue that in the short run money supply causes the inflation but does not cause the inflation in the long run.

\section{Modern Theory of Inflation}

According to this theory, "Change in aggregate level of prices is caused by the changes in aggregate demand and aggregate supply'. This theory is based on price determination theory. The theory analyze that both the demand side factors and supply side factors are responsible for causing the inflation. The inflation which occurs from demand side factors is called "Demand pull inflation" and the 
inflation which occurs from supply side factors is called "Cost push inflation".

\section{Significance of the study}

Conventionally, it is argued that consistently higher fiscal deficit causes inflation but findings of the empirically researched studies examining this phenomenon, does not give conclusive results which indicates that the relationship between monetary expansion and fiscal deficit and then with inflation may be less important in finding the level of inflation (Agha and Khan, 2006).

The case of Pakistan is not different from the rest of the developing countries. It is claimed that the fiscal deficit, large money growth, modes of financing the deficit and exchange rate depreciation are the main causes of inflation in Pakistan (Agha and Khan, 2006). Most of the studies have been conducted on this issue in Pakistan as well as other developing countries but the results are mixed and controversial which have no conclusive justification. Therefore, the present study is aimed to find empirically the relationship between inflation and other macro economic variables like government budget deficit and supply of money in Pakistan in long as well as short run. The study further investigates the lead lag relationship (direction of causality) between inflation and other macro economic variables e.g. money supply and budget deficit. This study is aimed to analyze the role of fiscal view of inflation for identification of inflation in Pakistan (Agha and Khan, 2006). The study used 51 years annual time series data for the first time in Pakistan, as most of the studies used only up to 40 years data.

\section{Objectives of the study}

The current study is aimed;

to analyze empirically the short run as well as long run relationship between inflation and other macro economic variables like fiscal deficit and money supply in Pakistan.

to investigate the lead lag relationship between inflation and other macro economic variables like fiscal deficit and money supply in Pakistan.

\section{Hypothesis of the study}

$\boldsymbol{H}_{0}$ : There is no long run relationship between inflation and other macro economic variables i.e. fiscal deficit and money supply

$\boldsymbol{H}_{1}$ : There is Long run relationship between inflation and other macro economic variables i.e. fiscal deficit and supply of money

$\boldsymbol{H}_{0}$ : There is no Short run relationship between inflation and other macro economic variables i.e. fiscal deficit and money supply

$\boldsymbol{H}_{1}$ : There is Short run relationship between inflation and other macro economic variables i.e. fiscal deficit and money supply

$\boldsymbol{H}_{0}$ : Inflation does not cause the fiscal deficit and money supply in Pakistan.

$\mathrm{H}_{1}$ a: Inflation causes the fiscal deficit and money supply in Pakistan. $\boldsymbol{H}_{\boldsymbol{0}} \boldsymbol{b}$ : Fiscal deficit and money supply do not cause the Inflation in Pakistan.

$\boldsymbol{H}_{1} \boldsymbol{b}$ : Fiscal deficit and money supply causes the Inflation in Pakistan.

\section{Review of literature}

The relationship between inflation and other macro economic variables is a general discussion in economic literature. Most of the economic experts have examined the association between inflation and other macroeconomic variables for many years by using different econometric techniques and different period of time for different countries. In most of the literature it has been examined that how budget deficits and supply of money affects the rate of inflation, which is shown in the literature cited below. Not too much attention has been given to the identification of causation running from both sides, i.e. how inflation is being affected by budget deficit and vice versa (Miller, 1983, Aghveli \& Khan, 1978; Agha and Khan, 2006; Metin, 1998 etc).

Aghveli and Khan (1978) conducted a study on inflation and budget deficit relationship theoretically and empirically. They concluded that inflation results in expending fiscal deficit which are mostly financed through the banking system leading to excessive liquidity in the system and thus creating inflation. Miller (1983) also analyzed that there exist simultaneous relationship between fiscal deficits and inflation.

Darrat (1985) conducted a study in U.S. to examine empirically the association between inflation and deficits during the period of post1960. The study used OLS (ordinary least square) technique, which showed that government budget deficits and growth in money affected inflation positively and significantly during the period of 1960-1970. The study further showed that budget deficits have a robust and significant relationship to inflation than growth of money. Bilquees and Faiz (1988) conducted a study in Pakistan on "Inflation in Pakistan: Empirical evidence on the Monetarist and Structuralist Hypothesis" to find out the factors and determinants of inflation in Pakistan in the long run. They found no positive significant relationship between the variables of the study.

Eisner (1989) conducted a study on "Budget Deficits: Rhetoric and Reality" to determine the effect of fiscal deficits on inflation to evaluate the structuralized deficits contributing to inflation. $\mathrm{He}$ founded that no positive and significant nexus between federal fiscal deficit and inflation exists.

Zelhorst (1990) in his study examined the interdependence of money supply and fiscal deficit leading to inflation in 44 less developed countries. The findings of the study concluded that no positive and significant relationship among fiscal deficit, supply of money and rate of inflation can be achieved.

Chaudhary \& Ahmad (1995) conducted a study in Pakistan on "Deficit, inflation and Money supply in Pakistan" to find out the inter-relationship among fiscal deficit, supply of money and inflation using Ordinary least square (OLS) model covering the period from 1973 to 1982 \& 1973 to 1992 taken from the economy of Pakistan. The variables of the study were inflation, fiscal deficit and money supply of the country. The study concluded that when the deficit is financed through internal sources especially borrowed from the banks causes the long run inflation in a country. It means that budget deficit and inflation has positive and significant association among them in Pakistan.

Akcay et al., (1996) conducted a study in Turkey on "The long run relationship between inflation and deficit to GNP ratio in Turkey" to find out the relationship empirically by using the annual data for a period of 46 years i.e. from 1948 to 1994 as well as from 1987 to 1995 on quarterly basis. The analysis of their study indicates that $1 \%$ rise in the deficit to GNP ratio brings $1.60 \%$ increase in inflation level in the long rung run by taking money supply constant.

Metin (1998) worked on an empirical study in Turkey on "The relationship between inflation and budget deficit in Turkey" to evaluate the empirical relationship between inflation and budget deficit in Turkish economy by using 37 years data over the period 1950-1987 taken from Turkish economy. By using co integration analysis, the results shows three stationary relationship in a set of variables like inflation, budget deficit, income growth and debt monetization, that budget deficit has a positive effect on inflation, real income growth negatively affect inflation immediately and positively affect inflation at second lag, to monetize the deficit through money increases also has a second-lag effect on inflation. Finally, it was concluded that fiscal deficit affect inflation in Turkish economy.

Terrones and Catao (2003) empirically evaluate the relationship between inflation and fiscal deficit for a period of 40 years (19602001), in more than hundred countries. The study has two definite aspects. At first it has used the model of inter temporal optimization to express that inflation in equilibrium is directly associated with budget deficit, measured by lower money supply. The approach concluded that the model is nonlinear and beneficial than semi logarithm. At Second, they developed a model which shows linkage between inflation and budget deficit "as dynamic intrinsically" which clearly differentiate the short run and long run.

Solomen and Wet (2004) conducted a study in Tanzania on "The effect of budget deficit on inflation; The case of Tanzania" to concluded the relationship between fiscal deficit and inflation rate empirically in the long run by applying the technique of co integration over the time period from 1967 to 2001, 34 years data taken from 
Tanzanian economy. Budget deficit, inflation, GDP and exchange rate were used as variables of the study. The results of co integration analysis show that the effect of fiscal deficit on inflation in Tanzania cannot be rejected under the supposition of long run neutrality of money growth. The study further affirmed that monetization of fiscal deficit significantly affects the inflation for increase in budget deficit. Srivyal and Venkata (2004) conducted a study in India on "Budget deficit and other macro economic variables in India" to detect the collaboration of fiscal deficit with other macroeconomic parameters such as GDP, nominal exchange rates, CPI and supply of money which brings significant importance to fiscal deficit and rate of exchange association by applying the test of co-integration and VECM (Vector Error Correction Model) for time period of 30 years (1970-2002). They used 32 years annual time series secondary data of fiscal deficit, GDP, nominal exchange rate, CPI and supply of money collected from the Indian statistics of Handbook which is provided by the Indian Reserve bank of India. The study concluded that the parameters are cointegrated under study and there is a two sided association between nominal effective exchange rates and fiscal deficit. But they have not found any positive association among fiscal deficit and GDP, money supply and inflation. It is also concluded that the gross domestic product (GDP) Granger causes budget deficit however budget deficit does not granger cause GDP.

Agha and Khan (2006) conducted a study in Pakistan on "An empirical analysis of fiscal imbalances and inflation in Pakistan" to evaluate the long term nexus between inflation and budget deficit in case of Pakistan, by using 30 years annual data of Pakistan economy covering the period from 1973 to 2003 . They used inflation, fiscal deficit and government borrowing as variables and co integration analysis as a model of the study. The study concluded a long term positive relationship between inflation and budget deficit in Pakistan. The analysis further showed that inflation is also affected by modes of financing the deficit.

Khan and Sclimmelfpennig (2006) conducted a study in Pakistan on "Inflation in Pakistan" to investigate the determinants which explain and estimate inflation in Pakistan using cointegration analysis over the period 1998-2005 on a monthly basis data collection. They used standard monetary variables, an activity variables, the wheat support price as well as the interest and exchange rates as a supply-side factor as a variables. The results show that monetary factors are the major causes of recent inflation, which affect inflation with a one year lag. Qayyum (2006) worked on a study empirically in Pakistan on " Inflation, supply of Money and Growth in Pakistan" to examine the linkage among inflation, growth and excess supply of money in Pakistan to investigate the monetaristic view of inflation which states that inflation is a monetary issue. To find the relationship, the study used Quantity theory of money as model of the study whereas money supply growth, growth in real GDP and rate of inflation as variables of the study which cover the period from 1960 to 2005 . The study affirmed that the relationship between inflation and money supply is positive and robust. The result revealed that money supply firstly, affect real GDP growth and secondly, money supply causes inflation to rise in Pakistan.

Kemal (2006) conducted a study in Pakistan on "Is inflation in Pakistan a monetary phenomenon?" to analyze the effect of monetary policy on inflation using cointegration analysis over the period from 1975 to 2003 on quarterly basis. The variables of the study are inflation, GDP, and money supply. The study concluded that money supply and inflation rates are correlated in the long run but not in the short run.

Makochekanwa (2008) conducted a study in Zimbabwe on "The effect of budget deficit on inflation in Zimbabwe" to identify the relationship between inflation and fiscal deficit in a long run by applying the technique of co integration analysis over the period 1980-2005, 25 years annual data taken from Zimbabwean economy. Inflation, budget deficit, exchange rate and GDP were used as variables of the study. The study concluded that money supply to balance the deficit have a positive effect on inflation.

Sarfaraz and Anwar (2009) conducted a study in Pakistan on "Fiscal imbalances and inflation; a case study of Pakistan" to test the long term association between inflation and budget deficit in Pakistan by applying 31 years annual data of time series taken from the economy of Pakistan over the period 1976-2007. The variables of the study were inflation, fiscal deficit, supply of money and borrowing (internal and external). The results of Cointegration test proved the entire relationship between inflation and budget deficit is positive and significant. The results also affirmed that financing of deficit through different modes are inflationary in Pakistan. Conclusions based on the results, revealed that the different modes of financing the fiscal deficit (external and internal borrowing) have varying effects on the rate of inflation.

Chimobi and Igwe (2010) conducted a combined study in Nigeria on "Budget deficit, inflation and money supply in Nigeria" to investigate the long run and causal relationship among inflation, budget deficit and money growth in Nigeria by applying technique of co integration analysis and Granger causality test, 35 years data over the period 1970-2005 was tested. The variables of the study were inflation, fiscal deficit and supply of money. The study concluded that there is a positive relationship among fiscal deficit, inflation and supply of money in Nigeria. The results indicated in empirical sense that deficit in budget, in first step affects money supply and then money supply leads to affect inflation. Money supply with respect to inflation is the proof of unidirectional causality from it to inflation. The results also showed that one percent change in budget deficit change the money growth at $0.94 \%$.

Mukhtar and Zakaria (2010) conducted a study in Pakistan on "Inflation, Budget deficit and Money supply: The case of Pakistan" to investigate the relationship among the relevant variables in the long run period. They used Johnson cointegration analysis over the data of time series on quarterly basis over the period from 1960 to 2007 . The result concluded that inflation and budget deficit in Pakistan have no significant inter-relationship between them in the long run during the analyzed period.

Samimi and Baygi (2011) conducted a study in Iran on "Inflation and Budget deficit; Sensitivity analysis to inflation and money supply in Iran" by using 18 years data collected on quarterly basis covering the period from 1990 to 2008, taken from the central bank of Islamic Republic of Iran. They used inflation, budget deficit, monetary base, money supply and GDP as variables of the study. Four simultaneous equation systems were used as a model of the study. The study examined the relationship in a two way between inflation and fiscal deficit in Iran using a model of simultaneous equation over the period 1990-2008. The findings revealed that fiscal deficit have a positive and significant effect on monetary variables at first round and then on inflation at the second round. The sensitivity analysis supports the strength of the estimation result with respect to the definition of inflation and money supply.

Cheah et al., (2011) conducted a study on "Budget deficit and inflation in thirteen Asian developing countries" to examine the relationship in long run, between inflation and fiscal deficit in thirteen (13) selected Asian developing countries, using Co integration analysis for long run and Granger causality for short run impact of fiscal deficit on inflation. They used 49 years data over the period 1950-1999 and used inflation, supply of money and fiscal deficit as variables of the study. The empirical results of the study unveiled that all the relevant variables i.e. inflation, money supply and budget deficit have the same order of integration of order one. Finally it is concluded that budget deficit have impact on inflation in the selected thirteen developing countries of Asia.

Oladipo and Akinbobola (2011) conducted a study in Nigeria on "Budget deficit and inflation in Nigeria; a causal relationship" to identify the nature and direction of causation between inflation and budget deficit in the economy of Nigeria using 35 years data covering the period from 1970 to 2005 taken from Nigerian economy. Budget deficit and inflation were served as variables of the study using Granger causality pair wise test and Augmented Dickey Fuller test. The study proved that budget deficit causes the inflation unidirectionally in Nigerian economy and further showed the study, that budget deficit have direct and indirect effects on inflation . 
Mehdi and Raza (2011) conducted a study in Iran on "Relationship between government budget deficit and inflation in the Iranian's economy" to find out the relationship between inflation and fiscal deficit using Autoregressive Distributed Lag (ARDL). They used 31 years data covering the period from 1975 to 2006 taken from the economy of Iran. Budget deficit and inflation were used as variables of the study. The study concluded that no significant correlation between inflation and government budget deficit exists in Iran but a significant and positive association exhibits between inflation and supply of money. So it has been recommended that an increase revenue and reduction in costs will be the best remedy to reduce the budget deficit. The study showed that one percent change in deficit will change the inflation to $1.82 \%$.

Kesavarajah and Amirthalingam (2012) conducted a study in Sri Lanka on "The Nexus between money supply and inflation in Sri Lanka" to examine the correlation between inflation and money supply in Sri Lanka over the period 1978 to 2010. They used inflation, money supply, budget deficit and exchange rate as variables of the study using Johnson and Juseliues multivariate cointegration test as a model of the study. Granger causality test and the test of stationarity i.e. Augmented Dickey Fuller (ADF) test of unit root were used also in the study. The study proved that the relationship of long run among the variables exists. Moreover, it is concluded also that there is a significant causality, which is running from supply of money towards inflation and exchange rate to inflation, while the causality running from budget deficit to inflation directly is insignificant. At last, it is recommended that money supply variable can be used as an effective policy instrument to maintain the price stability in Sri Lanka.

Saleem et al., (2013) studied empirically the "Determinants of inflation in Pakistan" to explore the major factors of inflation in Pakistan covering the period from 1990 to 2011. Among other factors of inflation, fiscal deficit was taken as a variables using Regression analysis through SPSS statistical package. The analysis does not support the hypothesis which states that the relationship between fiscal deficit and inflation is positive and significant in Pakistan.

At last, it is concluded that most of the research work has been done on the relationship among inflation, budget deficit and money supply in Pakistan and other countries of the world. The previous literature of most of the developing countries revealed that there is a positive long run relationship among these variables (Aghveli and Khan, 1978; Chaudhary \& Ahmad, 1995; Agha and Khan, 2006; Solomen and Wet, 2004; Samimi and Baygi, 2011; Oladipo and Akinbobola, 2011; Kesavarajah and Amirthalingam, 2012). While most of the studies regarding this relationship in developed countries have a fragile or no connection among these variables (Hondroyiannis and Papatrou, (1994, 1997); Ahking and Miller, 1985; Dawyer, 1982 and Metin, 1995). The studies that present no relationship among these variables in developing countries including Pakistan, are also present (Saleem et al., 2013; Mukhtar and Zakaria, 2010; Srivyal and Venkata, 2004; Eisner, 1989; Bilquees and Faiz, 1988).

\section{Research methodology}

Research Methodology is one of the beneficial factors in deciding the faith of the research. Well articulated methodology by keeping in view the objectives of the study, is the guarantee of the reliability and validity of the facts. The present study is aimed to analyze the short run and long run relationship between inflation, money supply and budget deficit of Pakistan economy using co-integration analysis. Cointegration analysis is a statistical tool for measuring time series data to find out the long relationship among the studied variables.

\section{Universe of the study}

The study is conducted in Pakistan based on historical annual time series data of Government budget deficit, inflation and money supply taken from different sources. The population size is based on 65 years annual data of budget deficit, inflation and money supply (19472012). The study is based on secondary data.

\section{Sampling design}

The population size is based on 65 years annual data and the Sample size includes 51 years annual time series data of Government budget deficit, inflation and money supply. The sample size comprised of annual time series data for 51 years from fiscal year (FY) 1960 to fiscal year (FY) 2010 with 51 numbers of total observations.

\section{Theoretical framework}

The influence of macroeconomic variables on inflation has been one of the alarming issues in economic literature. It has been examined and observed by economists and researchers like Mehdi and Raza, (2011); Oladipo and Akinbobola (2011), Chimobi and Igwe (2010), Sarfaraz and Anwar(2009), Kemal (2006), Qayyum (2006), etc in Pakistan as well as in other developing countries of the world that fiscal deficit, inflation and supply of money have causal relationship among themselves. The effect of budget deficit and supply of money on inflation is checked in this study. Based on this relationship we present a functional form of these three variables of the study in Pakistan. The model can be developed as specified below:

$\mathrm{CPI}=\mathrm{f}(\mathrm{M} 2, \mathrm{Bd})+\varepsilon$

The econometric form of the model can also be shown in natural logarithmic form, which is presented by the following function ;

$C P I_{t}=\alpha_{0}+\alpha_{1} \log M 2_{t}+\alpha_{2} \log B d_{t}+\varepsilon_{t}$

Where: $\mathrm{Bd}$ is fiscal deficit

M2 shows money supply,

CPI shows inflation,

$\alpha_{0}$ indicates the constant term, ' $t$ ' shows the trend of time and random error term is denoted by ' $\varepsilon$ '.

\section{Variables of the study}

The relationship between inflation and other macro economic variables have been analyzed by different economists, using different types of variables. All of them have used different models and found different results. Due to the special emphasis on the budget deficitinflation nexus, we used the following variables in our study.

\section{Budget deficit}

Government budget deficit is a situation when government's total expenditures exceed government's total revenues for a given period of time. Pakistan overall fiscal deficit which in essence is the conventional deficit of consolidated budget was used in the study.

\section{Inflation}

Inflation may be defined as the gradual and persistent rise in the general level of prices over a given time period. The inflation may be measured by indices, such as WPI (wholesale price index), SPI (sensitive price index), CPI (Consumer price index) and GDP deflator etc. Inflation is a proxy for CPI, following the standard practice. The CPI is regarded as most reliable and authentic tool of measuring inflation which is usually used in research studies (Agha and Khan, 2006; Solomen and De Wet, 2004; Metin, 1998). In Pakistan, the CPI is focused to use as a tool of measuring inflation in empirical studies because it measures with an extensive coverage of Three hundred and seventy five (375) types of goods in seventy one (71) markets comprised of thirty five (35) cities all over the country.

\section{Money supply}

Money supply is the volume of money which circulates in the country during a specific period of time or money supply is a total stock of money held by a government, people and banking system of a country during a specific period of time. Money supply is expressed in terms of monetary assets (M2), because it is the broader definition 
and main indicator of money supply which is used in most of the empirical studies.

\section{Data collection}

The State Bank of Pakistan, Federal Bureau of Statistics, and Ministry of finance of Pakistan and world development indicators (WDI) has been used as sources of secondary data collection

\section{Data analysis}

For finding the long run relationship among inflation, Government budget deficit and money supply, the cointegration analysis technique is used. The variables i.e. Inflation (CPI), money supply (LogM2) and budget deficit (Log BD) are included in the study. In an attempt to analyze the long run relationship between inflation, government budget deficit and money supply, cointegration approach is used to check the absence or presence of possible cointegration among the parameters of the study. Cointegration is a statistical tool for variables of time series data. When two or more than two time series variables share a common stochastic drift (Random walk) or move closely together, then they are said to be cointegrated.

Cointegration analysis should be used while testing the hypothesis concerning the inter-relationship among two or more than two variables having unit roots (i.e. integrated of at least order one (1)). When the data series have a limited length, like the most time series of economics, the Cointegration offers more powerful method for analysis. Cointegration is of two types:

a. Bi-variate cointegration (Between two variables).

b. Multi-variate cointegration (Among more than two variables).

As the variables are more than two in this study, therefore multivariate cointegration technique was used. It contains the possible presence of long run relationship among the relevant variables of the same order of integration by framing a cointegratting vector equation. Cointegration represent that, if two or more than two economic series share a random walk or move side by side over a long time, then these series may have a long run relationship, however the series are trended among them and the difference among them is fixed which means that the difference between them is stationary (Henry and Hall, 1989). Variables will have no long run relationship if there is no cointegration among the series because the series don't move side by side (Dickey et al., 1991).

\section{Estimation tools/techniques}

In order to analyze the long-run relationships among inflation, budget deficits and money growth in Pakistan, the following tools and techniques are used.

\section{Unit root test}

Using time series data for analysis, first of all it is necessary to check the stationarity property of the relevant variables. If the variables are stationary at level or at differences, then we proceed. Unit Root Test is a test which is used to check the stationarity of different variables. It estimates the order in which individual series under consideration are integrated. Because the time series data of macroeconomic mostly show non-stationary behavior at level form (Plosser and Nelson, 1982) and therefore leads to specious regression, therefore stationarity is checked first. The decision about adopting the technique is also dependent upon the order of integration of the data. The most popular test of unit root (no stationarity) is Augmented Dickey Fuller (ADF) test which is named because of Dickey and Fuller (1979, 1981) and the other is Phillip and Perron (PP) test named because of Phillips and Perron $(1987,1988)$. The test of ADF depends upon the law that the null hypothesis of unit root will be rejected and the alternative hypothesis of no unit root will be accepted. ADF is the modification of Dickey Fuller test in augmented form for small and complex series model.

The ADF test can be represented by the following regression:
$\Delta y_{t}=a_{0}+a_{1} y_{t-1}+\sum_{n=1}^{n} a_{1} \Delta y_{i}+e_{t}$

Where, $\mathrm{Y}$ represents a time series, $\Delta$ shows the first difference operator, $\mathrm{t}$ indicates a linear time trend, constant term is denoted by $\alpha_{0}, \mathrm{n}$ represents the maximum number of lags in the dependent variable, random error term is represented by ' $\mathrm{e}$ ', and we used the $\mathrm{ADF}$ test to estimate the stationarity level of the variables in the study.

\section{ARDL Approach to Co integration}

The Autoregressive Distributed Lag (ARDL) model is a dynamic model in which the effect of a regressor $x$ on $y$ occurs over time rather than all at once. The ARDL model is used to estimate the equation of the model to analyze the long run relationship among the variables of the model. The study used the general to specific approach because if the model in the general form is insignificant due to the probability values of most of the variables are insignificant so we cannot estimate an insignificant model so we go for the specific model. We dropped out those variables whose probabilities are highly insignificant and we go from general model to specific in this way. The study employed the Autoregressive Distributed Lag Model (ARDL) approach to cointegration proposed by Pesaran et al.(2001), because of the following reasons; (a) As the study has small sample size comprised of 51 observations(i.e. small range: 30 to 80 as in this study), The results of F-test (Bound testing) show robustness for small samples. (b) The order of integration of variables of the study are different, i.e. CPI is stationary at level $1(0)$ and Bd and M2 are stationary at first difference 1(1), and none of the variables are 1(2) or higher, (c) The short-run and long-run relationships of the model can be can be estimated at the same time (Aregbeyen and Ibrahim, 2012).

Therefore above all these points justified to use ARDL Model to determine the long run relationship among the variables of the study in Pakistan. The main aim of using ARDL model is to estimate the equation of the model to find out the long run relationship between the variables of the model. We use the general to specific approach to find out the long run relationship. We drop out those variables whose probabilities are highly insignificant and we go from general model to specific in this way.

The general form of ARDL is specified below.

$\Delta \mathrm{CPI}=\alpha_{\mathrm{o}}+\beta_{1} \mathrm{CPI}_{\mathrm{t}-1}+\beta_{2} \log \mathrm{BD}_{\mathrm{t}-1}+\beta_{3} \log \mathrm{M} 2_{\mathrm{t}-1}+\sum_{i=1}^{k} \delta_{1 i} \Delta \mathrm{CPI}_{\mathrm{t}-\mathrm{i}}$

$+\sum_{i=1}^{k} \delta_{2 i} \Delta \log \mathrm{BD}_{\mathrm{t}-1}+\sum_{i=1}^{k} \delta_{3 i} \Delta \log \mathrm{M} 2_{\mathrm{t}-1}+\varepsilon_{t}$

Where, CPI denotes consumer price index which shows inflation, the first difference operator is denoted by $\Delta$, constant term is represented by $\alpha_{0}$, k represent the lag length criterion, time trend is shown by $\mathrm{t}$, $\delta$ is the coefficient for measuring the speed of adjustment, $\varepsilon_{t}$ is the error term.

\section{For long run \\ $\mathrm{CPI}=\alpha_{\mathrm{o}}+\beta_{1} \mathrm{CPI}_{\mathrm{t}-1}+\beta_{2} \log \mathrm{BD}_{\mathrm{t}-1}+\beta_{3} \log \mathrm{M} 2_{\mathrm{t}-1}+\varepsilon_{t}$}

\section{For short run}

$\Delta \mathrm{CPI}=\alpha_{\mathrm{o}}+\sum_{i=1}^{k} \delta_{1 i} \Delta \mathrm{CPI}_{\mathrm{t}-\mathrm{i}}+\sum_{i=1}^{k} \delta_{2 i} \Delta \log \mathrm{BD}_{\mathrm{t}-1}+\sum_{i=1}^{k} \delta_{3 i} \Delta \log$ $\mathrm{M} 2_{\mathrm{t}-1}+\varepsilon_{t}$

\section{Granger causality test}

If two or more than two variables have a co-integration then there must be causation in at least one direction which shows the direction 
of causality between the variables. Granger causality test is a test which is used to find out the lead lag relationship among the variables. The direction of causality of the variables is tested in this test. G-Causality was developed in 1960, and has been widely used in economics since the 1960 .

In order to conclude whether the lagged and current values of one variable affect the other, Granger causality tests are conducted. Granger causality test suggests that if two variables have cointegration among them, then these variables must be granger causes in at least one direction. This causation of cointegrated variables is then applied when vector error correction model (VECM).

If the variables have no co-integration among themselves, then the unrestricted Vector auto regressive (VAR) model is estimated, which is shown by the following equations;

$$
\begin{aligned}
& \Delta B d_{t}=\sum_{i=1}^{n} b_{2 t} \Delta B d_{t-1}+\sum_{i=1}^{n} c_{2 t} \Delta \operatorname{Inf} f_{t-1}+\sum_{i=1}^{n} d_{2 t} \Delta M_{t-1}+e_{2 t} \\
& \Delta \operatorname{Inf} f_{t}=\sum_{i=1}^{n} b_{2 t} \Delta B d_{t-1}+\sum_{i=1}^{n} c_{2 t} \Delta \operatorname{Inf} f_{t-1}+\sum_{i=1}^{n} d_{2 t} \Delta M_{t-1}+e_{2 t} \\
& \Delta M_{t}=\sum_{i=1}^{n} b_{3 t} \Delta B d_{t-1}+\sum_{i=1}^{n} c_{3 t} \Delta \operatorname{Inf} f_{t-1}+\sum_{i=1}^{n} d_{3 t} \Delta M_{t-1}+e_{3 t}
\end{aligned}
$$

In the above equation, $\mathrm{Bd}$ represents budget deficit, inf represent inflation, $\mathrm{M}$ represent money supply, $\Delta$ shows first difference operator, e1, e 2 and e 3 shows random errors, $t$ is time trend and $n$ indicates number of maximum lag length which is measured empirically by Schwarz Criterion (SC).

\section{Results and discussion}

In this chapter the study analyzed the data in order to find out the final results. The study is based on the time series data covering the time period from 1960 to 2010 . The data used in the study is time series data and the nature of data is secondary. The secondary time series data mostly shows non-stationary behavior at level form and become stationary at first or second difference. In order to know the level of stationarity and analyzing the data, the study has used some tests as below:

\section{Unit root test}

The present study shows the analysis of time series data using unit root test. Before choosing the appropriate econometric framework one should know the results of the unit root test, so it is performed earlier then go for some econometric framework. To analyze time series data, the first step is to check out the level of stationarity of the relevant variables in order to find their order of integration. There are so many unit root tests used in order to find out the stationarity level of the data like Augmented Dickey fuller (ADF), Phillips Perron (PP) and John Denis and Alok Bhargava tests for unit root but the current study uses the Augmented Dickey Fuller (ADF) test to determine the presence or absence of unit root in each of relevant variable as it is very useful in the case of small samples and it gives very good results. The ADF test was used in order to check all the variables at their level form as well as at differences. The results of ADF test at level are reported below:

Table 4.1: ADF test results for stationarity at level (with trend and intercept)

\begin{tabular}{|l|l|l|l|}
\hline Variables & Critical value & ADF value & Probability \\
\hline CPI & -2.921175 & -3.248980 & 0.0229 \\
\hline Log BD & -3.502373 & -1.403933 & 0.8478 \\
\hline Log M2 & -3.502373 & -2.579501 & 0.2910 \\
\hline
\end{tabular}

Note: At $5 \%$ level of significance.

Source: Estimation of Author by using E-views 6 .
Table 4.1 depicts that the ADF test is used with both trend and intercept because the results are insignificant with trend or with intercept separately. The results of ADF unit root test shows that not all of the data are stationary at level form. The above table also shows that Consumer Price Index (CPI) is stationary at level form but Budget Deficit (BD) and Money Supply (M2) are not stationary at level form. First the CPI was checked on the level form using the ADF criteria and the result showed that the CPI was stationary at level form. The ADF value for $\mathrm{CPI}$ is greater than critical value at $5 \%$ significance level so we reject the null hypothesis that there is unit root and accept the alternative hypothesis that there is no unit root (Fuller, 1976). The p-value is also significant which shows that the variable is stationary at level form. Then we checked the $2^{\text {nd }}$ variable Budget Deficit (BD) using the ADF criteria. The result of Unit root showed that the variable is non-stationary at level form because the $\mathrm{ADF}$ value is less than the Critical value at $5 \%$ level of significance as shown in the table, so we accept the null hypothesis of unit root that there is unit root present in the data. The p-value is also insignificant which shows that there is unit root present in the data. At last we checked the Money Supply (M2) by using ADF criteria. The result of unit root test indicate that M2 is not stationary at level because ADF value is less than critical value at $5 \%$ level of significance and we accept the null hypothesis that unit root exists at level as also shown by p-value (Fuller, 1976). So then we go for the $1^{\text {st }}$ difference. The CPI is stationary at level form therefore it is excluded from checking the results at first difference and therefore is not mentioned in the following table. The results of $1^{\text {st }}$ difference of Budget Deficit and Money Supply are shown in the table 4.2 as follows:

Table 4.2: ADF test results for stationarity at First difference (With trend and intercept)

\begin{tabular}{|l|l|l|l|}
\hline Variables & Critical value & ADF value & Probability \\
\hline Log BD & -3.504330 & -8.069413 & 0.0000 \\
\hline Log M2 & -3.504330 & -6.080408 & 0.0000 \\
\hline
\end{tabular}

Note: At $5 \%$ level of significance. Applied hypothesis of unit root rejection of Mackinnon (1991) critical value.

Source: Estimation of Author by using E-views 6.

The unit root results of the above table 4.2 of the $1^{\text {st }}$ difference of the two variables Budget Deficit and Money Supply are as such. The Budget Deficit is stationary at $1^{\text {st }}$ difference because the ADF value of $\mathrm{BD}$ is greater than that of the critical value of the variable at $5 \%$ level of significance. The p-value also supports the result of the ADF value of unit root and showed that the p-value is significant. The Money Supply was also checked at $1^{\text {st }}$ difference using the ADF criteria and the results showed that $\mathrm{M} 2$ is stationary at $1^{\text {st }}$ difference looking into the $\mathrm{ADF}$ value which is greater than the critical value at $5 \%$ level of significance. The results of $\mathrm{p}$-value also support the ADF decision.

Thus the unit root test shows that one variable is stationary at level form and remaining two variables are stationary at $1^{\text {st }}$ differences. When the variables are stationary at different order of integration, then we go for the ARDL technique to estimate the results. We go for the Bound test approach in order to know the co-integration.

\section{Results of ARDL model}

The Autoregressive Distributed Lag (ARDL) Model is a dynamic model in which the effect of a regressor $x$ on $y$ occurs over time rather than all at once. The ARDL model is used to estimate the equation of the model to find out the long run relationship between the variables of the model. We drop out those variables whose probabilities are highly insignificant and we go from general model to specific in this way.

Table 4.3: General Model of ARDL for Inflation, Budget Deficit \& Money Supply

\begin{tabular}{|l|l|l|l|l|}
\hline Variable & Coefficient & $\begin{array}{l}\text { Std. } \\
\text { Error }\end{array}$ & $\begin{array}{l}\text { t- } \\
\text { Statistic }\end{array}$ & Prob. \\
\hline CPI(-1) & -0.372845 & 0.116066 & - & 0.0025 \\
& & & 3.212358 & \\
\hline LOGM2(-1) & 0.160749 & 0.945878 & 0.169946 & 0.8658 \\
\hline
\end{tabular}




\begin{tabular}{|c|c|c|c|c|}
\hline $\operatorname{LOGBD}(-1)$ & -0.618405 & 4.825152 & $\begin{array}{l}-128163 \\
0.128\end{array}$ & 0.8986 \\
\hline $\mathrm{D}(\mathrm{LOGM} 2(-1))$ & -5.577426 & 25.71972 & $\begin{array}{l}- \\
0.216854\end{array}$ & 0.8293 \\
\hline $\mathrm{D}(\mathrm{LOGBD}(-1))$ & -2.698631 & 8.189391 & $\begin{array}{l}- \\
0.329528\end{array}$ & 0.7434 \\
\hline $\mathrm{C}$ & 4.801092 & 12.63853 & 0.379878 & 0.7059 \\
\hline R-squared & 0.727510 & & & \\
\hline $\begin{array}{l}\text { Adjusted R- } \\
\text { squared }\end{array}$ & 0.694298 & & & \\
\hline F-statistic & 2.688720 & & & \\
\hline $\begin{array}{l}\text { Prob (F- } \\
\text { statistic) }\end{array}$ & 0.022467 & & & \\
\hline
\end{tabular}

the probability value is insignificant and thus we accept the null hypothesis i.e. there is no co-integration against alternative hypothesis that there is co-integration. The F-statistics value gathered from the above table of Wald test showed that it is insignificant and we accept the null hypothesis by rejecting the alternative one. So it shows that the relationship between the variables of the model is not significant in the long run.

\section{Bound Testing Approach to Cointegration: Result of F-Test}

Looking into the Pesaran table we check for the co-integration between the variables. When the calculated F-statistic value is more than the critical upper bounds value then there is present cointegration between the variables and we accept the alternative

As it can be seen from the table 4.3 of general model of ARDL that most of the p-values are insignificant, although the overall model is good because the overall probability (F-statistic) of the model is significant but the individual p-values of the variables are insignificant, so we cannot estimates the results from the model therefore the study goes from general to specific model in such a way that the variables with highly insignificant values are dropped out one by one till most of the p-values of variables become significant. In this way the study proceed to a specific model.

Table 4.4: Specific Model of ARDL for Inflation, Budget Deficit \& Money Supply

\begin{tabular}{|l|l|l|l|l|}
\hline Variable & Coefficient & $\begin{array}{l}\text { Std. } \\
\text { Error }\end{array}$ & $\begin{array}{l}\text { t- } \\
\text { Statistic }\end{array}$ & Prob. \\
\hline CPI(-1) & -0.371314 & 0.112741 & - & 0.0019 \\
& & & 3.293513 & \\
\hline $\begin{array}{l}\text { D(LOGM2(- } \\
\text { 1)) }\end{array}$ & -5.492506 & 24.75241 & - & 0.0422 \\
\hline $\begin{array}{l}\text { D(LOGBD(- } \\
\text { 1)) }\end{array}$ & -3.286219 & 7.252058 & -221898 & \\
\hline C & 3.688928 & 1.715491 & 2.150363 & 0.0369 \\
\hline R-squared & 0.620223 & & & \\
\hline $\begin{array}{l}\text { Adjusted R- } \\
\text { squared }\end{array}$ & 0.590238 & \multicolumn{3}{|l|}{} \\
\hline F-statistic & 5.005947 & & \\
\hline $\begin{array}{l}\text { Prob (F- } \\
\text { statistic) }\end{array}$ & 0.004429 & \multicolumn{3}{|l}{} \\
\hline
\end{tabular}

The above data results of the specific model showed that the specific model is the significant model as most of its variables are significant CPI(-1), D(LOGM2(-1)) and $\mathrm{D}(\operatorname{LOGBD}(-1))$ have significant $\mathrm{p}$ values therefore we can say that the model is significant and we can estimate the results. The long-run relationship or the co-integration effect is checked by applying the Bound testing approach of ARDL.

\section{Wald test}

The Wald test is a test which is used to test the joint and individual effect of independent variables on the explained variable. The Wald test may be defined as parametric statistical test in which a relationship between or within a set of data may be shown as a statistical model with variables to be found from a sample and it is used to test the accurate values of the variables based on the sample estimate.

The Bound testing approach of ARDL may be used to find out the cointegration if any in the model. The value of F-statistics is then used to check the equilibrium relationship in long run. First the Wald test is run and the value of F-statistics is find out from the test and then the calculated value of F-statistics is used in the Bound test to check for the co-integration.

Table 4.5: Wald Coefficient Test for Significance

\begin{tabular}{|l|l|l|l|}
\hline Test- Statistic & Value & $\begin{array}{l}\text { Degree } \\
\text { of freedom }\end{array}$ & Probability \\
\hline F-statistic & 3.81309 & $(3,45)$ & 0.1624 \\
\hline Chi-square & 11.43929 & 3 & 0.0654 \\
\hline
\end{tabular}

Here the result of the Wald test showed that no combined effect of the independent variables on the dependent variable is present because hypothesis but when the calculated F-statistic value is less than the critical lower bounds value then it means that there is no cointegration between the variables and we accept the null hypothesis. However, when the calculated F-statistic value falls within critical upper and lower bounds values, no meaningful decision could be taken about co-integration status.

Table 4.6: ARDL bound test result for Co-integration (with $5 \%$ and $10 \%$ critical value)

\begin{tabular}{|l|l|}
\hline & $\mathrm{K}=1$ (lag length) \\
\hline Computed F-Statistic: & 3.813096 \\
P-value & $(0.1624)$ \\
\hline 5\% critical bound value & \\
Lower: & 4.903 \\
Upper: & 5.872 \\
\hline 10\% critical bound value & \\
Lower: & 4.205 \\
Upper: & 5.109 \\
\hline Outcome & No Co-integration \\
\hline
\end{tabular}

Notes: The critical values are extracted from Pesaran et al. (2001). Figure within parenthesis indicate probability.

Looking into the Pesaran table we check for the co-integration between the variables. As we can see from the above table 4.6 that the computed F-statistics value is less than the lower critical bound value at $5 \%$ and $10 \%$ significance level in the Pesaran table. Therefore, it is concluded that no cointegration exists between the variables of the study. On this basis, it is concluded that long run relationship among the variables of the study does not exist. The prob(F-statistics) value of overall model is good i.e. 0.004 . The results concluded that there is no co-integration between the variables because the F-statistics (3.813) value is less than the lower critical bounds value at $5 \%$ in the Pesaran et al. (2001) table. The p-value also shows insignificance which means that there is a lack of co-integration between the variables. Bound test results showed that the value of F-statistics is less than the lower bound of the critical value at both $10 \%$ and $5 \%$ significance level.

This shows that the long-run relationship between Inflation (CPI) and other macroeconomic variables like supply of Money and fiscal deficit, does not exists in Pakistan. The results of the study are supported by the findings of Bilquees (1988), Neyapti (1998) and Mukhtar and Zakaria (2010), but contrary to the conclusion of Agha and Khan (2006), Choudhary and Ahmad (1995) and Sarfaraz and Anwar (2009). The second objective of our study, which is to find the lead lag relationship among the variables, need not to explore the direction of causality because there is no significant long run relationship among the variables. Therefore there is no lead lag relationship among the variables of the study.

\section{Short run relationship (VAR Model Results)}

After it has been confirmed that there is no long run relationship, we proceed to find out the short run effect among the variables. Most of the economists used VAR model to analyze the effects of monetary policy, but in lack of cointegration, they also have used VAR context for fiscal policy (Heppke-Falk et al., 2006).

Table 4.7: VAR Model Estimates for Short Run Relationship 


\begin{tabular}{|l|c|c|c|}
\hline CPI(-1) & 0.642068 & 0.000637 & 0.000648 \\
\hline & $(0.11173)$ & $(0.00066)$ & $(0.00216)$ \\
\hline & {$[5.74680]$} & {$[0.97082]$} & {$[0.29980]$} \\
\hline & - & 0.999814 & -0.010597 \\
& 0.317579 & & \\
\hline & $(0.85272)$ & $(0.00500)$ & $(0.01651)$ \\
\hline LOGBD(-1) & {$[0.37243]$} & {$[199.767]$} & {$[-0.64198]$} \\
\hline & -0.294666 & 0.021908 & 0.883555 \\
\hline & $(4.27080)$ & $(0.02507)$ & $(0.08268)$ \\
\hline C & {$[-0.06900]$} & {$[0.87397]$} & {$[10.6869]$} \\
\hline & 2.409521 & -0.014272 & 0.417575 \\
\hline & $(11.4038)$ & $(0.06693)$ & $(0.22076)$ \\
\hline R-squared & {$[0.21129]$} & {$[-0.21323]$} & {$[1.89154]$} \\
\hline Adj. R-squared & 0.723955 & 0.999255 & 0.778719 \\
\hline
\end{tabular}

The normality test mostly used is the Jarque-Bera test which checks out the normality distribution of the residuals. The normality test of Breusch-Godfray is used to find out whether the residuals in the model are normally distributed or not. This test checks out the normal distribution of the residuals also in terms of the normal distribution of the skewness and kurtosis. The Jarque-Bera test shows that the residuals are normally distributed as the values of skewness and kurtosis are normal. The probability value of the test $(0.946)$ is also the large and insignificant so we cannot reject the null hypothesis i.e. there is normal distribution of residuals in the model. The results are shown below:

The data results showed that there is no long run relationship as we got from the ARDL model in but there is short run relationship between the variables of the model which can be seen from the above table 4.7. The short-run estimates of the model can also be drawn from the VAR model as there is no co-integration vector present in the model so we can go for the VAR model. The VAR model results show that there is a positive short-run relationship between Inflation (CPI) and money supply. The results further estimate that if there is a $1 \%$ increase in money supply there will be $0.31 \%$ increase in the inflation of the country. Similarly there is a positive relationship between inflation and Budget Deficit of the country i.e. if there is a $1 \%$ increase in the budget deficit of the Country then there will be $0.29 \%$ increase in the inflation of the country. This concludes that there is only short-run relationship between the Inflation, Budget Deficit and Money supply of Pakistan in the study period.

\section{Diagnostic Checking}

\section{Breusch-Godfrey LM Serial Correlation}

The Breusch-Godfrey test of serial correlation is used to check out the serial correlation between the variables of the model. "Breusch and Godfray formulated this LM test in order to check for autocorrelation and it allows for the lagged values of the regressands and autoregressive higher order schemes like AR1 and AR2" [Gujrati (2004)]. The results of the test show that the serial correlation problem is not present in the model as the probability value of the test is insignificant and we cannot reject the null hypothesis which states that there is no serial correlation present in the model. So this is a good sign for the model.

Table 4.8: Breusch-Godfrey LM Serial Correlation

\begin{tabular}{|l|l|l|}
\hline F-statistic & 0.592662 & Prob. F(2,43) \\
\hline Obs $^{*}$ R-squared & 1.314482 & Prob. Chi-Square \\
\hline
\end{tabular}

\section{Heteroscadesticity Test}

"The Heteroscadesticity test is formulated to find out whether the residuals in a model are homoscedastic or not. White test is statistical test that establish whether the residual variance of a variable in the given model is constant or not, that is it checks for the homoscedasticity. It can be used for both the heteroscadesticity and the specification error or one of them" (Gujarati 2004). Heteroscadesticity is the absence of homoscedasticity i.e. the variables of the model are not of the same spread. The results of the Breusch-Godfray Heteroscadesticity show that there is no heteroscadesticity problem present in the model as the probability value opposite to the observed R-square is insignificant and it concludes that we cannot reject the null hypothesis i.e. there is no heteroscadesticity problem present in the model.

Table 4.9: Breusch-Godfrey Heteroscadesticity Test

\begin{tabular}{|l|l|l|l|}
\hline F-statistic & 1.760578 & Prob. F(3,45) & 0.1683 \\
\hline Obs $^{*}$ R-squared & 5.147096 & $\begin{array}{l}\text { Prob. Chi- } \\
\text { Square(3) }\end{array}$ & 0.1613 \\
\hline
\end{tabular}

\section{Normality test}




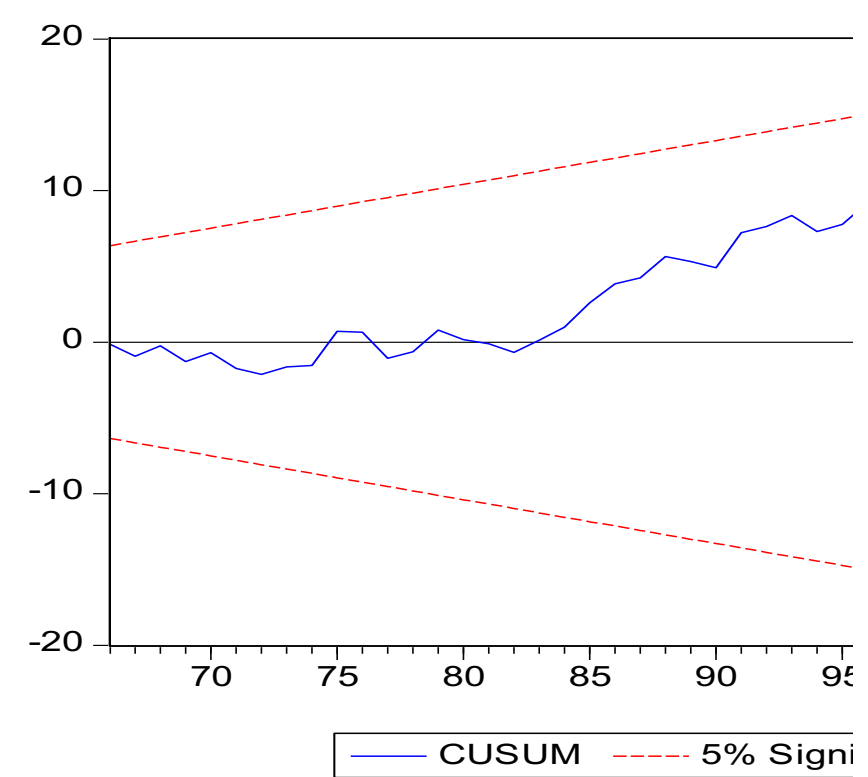

Fig. 4.2. Cumulative Sum of Recursive Residuals (CUSUM)

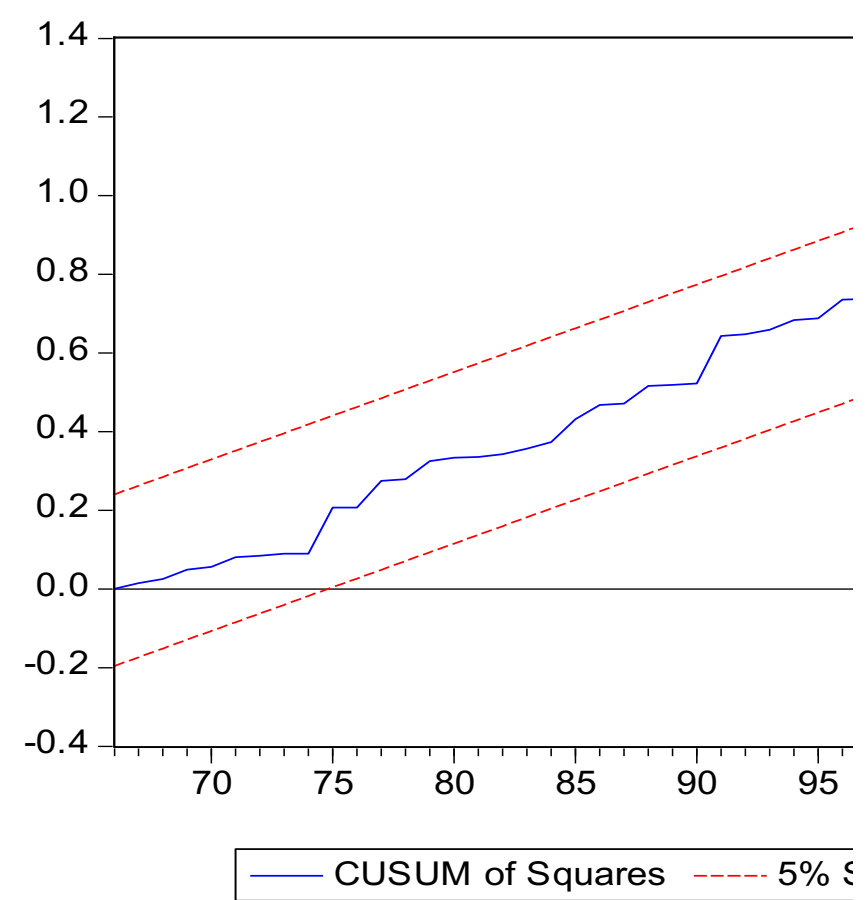

Fig. 4.3. Cumulative Sum of Squares of Recursive Residuals (CUSUM Squares)

\section{Summary, conclusion and recommendations}

\section{Summary}

The study is aimed to find out the short run and long run relationship between inflation and other macroeconomic variables in Pakistan. The other macroeconomic variables are budget deficit and money supply. The population size consists of 65 annual time series data of inflation, budget deficit and money supply covering the period from fiscal year 1947 to fiscal year 2012. The sample size is based on annual time series data of inflation, budget deficit and money supply from fiscal year 1960 to fiscal year 2010 comprised of 51 observations. The data used in the study is secondary data and is collected from the State Bank of Pakistan, Federal Bureau of Statistics and World Development Indicators (WDI). The bound testing approach to co-integration and VAR model, established within an Autoregressive distributed lag (ARDL) is used to find out the short run and long run relationship between the studied variables. Augmented Dickey Fuller (ADF) test of unit root was applied to check the stationarity status of the variables. It is necessary to check the stationarity first because the appropriate econometric framework depends upon the order of integration of the variables.

The results of ADF test shows that inflation is stationary at level form and the other two variables budget deficit and money supply are stationary at first difference, therefore the study used ARDL approach to co-integration. The results of ARDL model indicate that there is no long run relationship between inflation and other studied macroeconomic variables of the study in Pakistan, as the F-statistics value calculated through Wald test lies below the lower critical bound value of the bound test, which indicate no long run relationship. Although, the results of VAR model shows that there is only short run relationship between inflation other macroeconomic variables of the study. The results of VAR model further indicate that one percent change in Budget deficit and money supply caused the inflation by 0.29 and 0.31 times respectively in the short run.

\section{Conclusion}

In this study, an attempt is made to analyze the factors which are responsible for increasing the inflation rate of the country and to determine empirically the role of government budget deficit and money supply in the determination of inflation for the time period from 1960-2010. The ARDL model results showed that there was no long-run relationship present between the variables of the model as there was no co-integrating vector or equation present in the model. The results further showed that there is only short-run positive relationship between the inflation and the budget deficit of the country using the VAR model. The results also showed that, there is no lead lag relationship too among the variables. It means that there are other factors which are responsible for raising inflation in Pakistan in the long run.

At last it is argued that in the real world there may be other factors which causes the inflation in the country i.e. war on terror, rupee devaluation, cost push factors, higher import prices, raw material prices, political instability, less efficient tax collection, recession in the country and a depressed economy which breakdown this relationship because of a fall in the circulation of money, in which the money supply increases without causing inflation,

\section{Recommendations}

The following recommendations are suggested in this study for the government of Pakistan.

The government policies in which they have targeted the control of inflation may give good results if they are targeted at generating the domestic economic resources instead of reducing fiscal deficit.

The foreign and domestic investors should be encouraged by providing them full security and freedom of access to investable funds in order to support the real sector growth.

The dependence of Pakistan on the foreign and domestic loaning to finance the deficit is not a good policy. This contributes to budget deficit of the country again. So there should be less reliance on these foreign financing or even these should be avoided by generating domestic resources.

The improvement in the GDP growth will enhance the overall growth and development of the economy and will obviously leave positive effects on the economy. This can also be helpful in reducing the rate of inflation.

\section{References (Literature cited)}

Aghevei, B. and M.S. Khan. (1978). Government Deficits and Inflationary Process in Developing Countries. International Monetary Fund (IMF) Staff Papers. Vol.25 (September). Washington, D.C, The IMF.

Bilquees and Faiz. (1988). Inflation in Pakistan: Empirical Evidence on the Monetarist and Structuralist Hypothesis. The Pakistan Development Review, 27(2): pp.109-129. 
Chaudhry, M. A. and N. Ahmed. (1995). Money supply, deficit and inflation in Pakistan. The Pakistan Development Review, 34: 4(3): pp.945-956.

Chimobi, O. P. and O. L. Igwe. (2010). Budget deficit, money supply \& inflation in Nigeria. European journal of Economics, Finance and Administrative sciences, ISSN. 1450-2275.

Dehaan and Zelhorost. (1990). The impact of Government Deficit on Money growth in Developing countries. Journal of International Money and Finance, 9(4): pp. 455-469.

Fuller, W. A. (1976). Introduction to Statistical Time Series, John Wiley and Sons, New York, 373.

Eisner, R. (1989). Budget Deficits: Rhetoric and Reality. Journal of Economic Perspectives, Vol. 3: pp. 73-93.

Habib ullah, M. S., C. K. Cheah and A. H. Baharom. (2011). Budget deficit and inflation in thirteen Asian developing countries. International journal of business and social sciences, 2 (9): issue 19, http:// www.eurojournals.com.

Idrees, A. and M. Saleem Khan. (2006). An empirical analysis of fiscal imbalances and inflation in Pakistan. SBP Research bulletin, 2 (2).

Kemal, M. A. (2006). Is inflation in Pakistan a monetary phenomenon. The Pakistan development Review, 45 (2): pp. 213-220.

Khan, M. S. \& A. Schimmelpfennig. (2006). Inflation in Pakistan. The Pakistan development review, 45 (2): pp.185-202.

Makochekanwa, A. (2008). The effect of budget deficit on inflation in Zimbabwe. Online at http://mpra.ub.uni-muenchen.de/24227/. MPRA paper No. 24227.

Mehdi, S. and M. Reza. (2011). Relationship between Govt. budget deficit and inflation in Iran's economy. Information management and business review, 2(5): pp. 223-228.

Metin, K. (1998). The relationship between inflation and budget deficit in Turkey Journal of Business \& Economics Statistics, 16 (4): pp. 412-422.

Mukhtar, T. \& M. Zakaria. (2010). Budget deficit, Money supply and Inflation: The case of Pakistan. Pakistan institute of development economics.

Neyapti. (1998). Budget deficit and Inflation: An analysis in the light of Roles of Central Bank Independence and financial Market Development.
Working papers, No.997, Department of Economics, Ankara: Bilkent University.

Oladipo, S. O. and T. O. Akinbobola. (2011). Budget deficit and inflation in Nigeria: A causal relationship. Journal of emerging trends in Economics and management sciences (JETEMS), 2(1): pp. 1-8, (ISSN: 2141-7024).

Onwioduoicit, E. A. (2007). Fiscal deficit and inflation dynamics in Nigeria: An empirical investigation of causal relationships. CBN Economic and Financial review, 37 (2): pp. 1-16.

Qayyum, A. (2006). Money, Inflation, and Growth in Pakistan. Pakistan Institute of Development Economics, MPRA Paper No. 255, Online at http://mpra.ub.uni-muenchen.de/2005/.

Samimi, A. J. and S. Jamshedbaygi. (2011). Budget deficit and inflation: A sensitivity analysis to inflation and money supply in Iran. Middle East journal of scientific research, 8(1): pp. 257-260.

Sarfaraz, A. and M. Anwar. (2009). Fiscal imbalances and inflation: A case study of Pakistan. Pakistan journal of social sciences (PJSS), 29 (1): pp. 39-50.

Shabbir, T. and A. Ahmed. (1994). Are government budget deficit inflationary? Evidence from Pakistan. The Pakistan development review, 33:4(2): pp. 955-967.

Solomen, M. and W. A. de Wet. (2004). The effect of budget deficit on inflation: The case study of Tanzania. SAJEMS NS 7 (1).

Srivyal. and S. Ventaka. (2004). Budget deficit and other macro economic variables in India. Applied Econometrics and International Development, AEEADE. Vol.4-1.

Saleem et.al. (2013). Determinants of Inflation in Pakistan. Interdisciplinary journal of Contemporary Research in business, Vol.4, No.9, ijcrb.webs.com.

Tiwari, A. K. and A. P. Tiwari. (2011). Fiscal deficit and inflation: An empirical analysis for India. The Romanian economic Journal, Year XIV, 42 (1). 